\title{
Ideał liberalno-wolnościowy (liberal-free ideal) w dziejach edukacji liberalnej*
}

Rozważmy nastawienie orędowników Nowej Filozofii i Nowej Nauki względem szkół. Większość popierała Francisa Bacona, dystansując się wobec ustabilizowanych instytucji, w sprzeciwie wobec ich szkolnych i dżentelmeńskich orientacji. Hobbes znudzony oxfordzkim arystotelizmem chciał, aby na uniwersytecie wykładana była raczej jego własna doktryna aniżeli starożytna. Kartezjusz nie uważał pamięciowej nauki sylogizmów czy dzieł starożytnych autorytetów za przydatną w dochodzeniu do prawdy, a Locke postrzegał dysputy uniwersyteckie jako bezużyteczne ${ }^{1}$. Ataki na wykładowców utrzymywały się w osiemnastym wieku, jak wtedy, gdy Gibbon drwił

* Reprinted by permission of the Publisher. From Bruce A. Kimball, Orators and Philosophers: A History of the Idea of Liberal Education, New York: Teachers College Press, s. 125-143. Copyright (C) 1986 by Bruce A. Kimball. All rights reserved.

1 T. Hobbes, Leviathan; or, The Matter, Forme and Power of a Commonwealth, Ecclesiastical and Civil, red. C. B. Macpherson, Baltimore: Penguin 1968, ss. 727-728 [T. Hobbes, Lewiatan, przeł. Cz. Znamierowski, Warszawa: Fundacja Aletheia, 2005]; R. Descartes, Rules for the Direction of the Mind, w: Philosophical Works of Descartes, przel. E. S. Haldane, G. R. Ross, Cambridge: Cambridge University Press 1911, reguły 3, 7, 14 [R. Descartes, Reguly kierowania umystem, przeł. L. Chmaj, Kęty: Wydawnictwo Antyk, 2002]; J. Locke, Of the Conduct of the Understanding, red. F. W. Garforth, New York: Teachers College Press 1966, sekcja 7, 29, 31, [J. Locke, O właściwym używaniu rozumu, w: Rozważania dotyczace rozumu ludzkiego, przeł. B. J. Gawecki, Warszawa: Państwowe Wydawnictwo Naukowe 1955]. 
z dogmatyzmu uniwersytetów, a Hume sugerował, że należy dokonać radykalnego przeglądu uniwersyteckich bibliotek:

Jeśli przejęci tymi zasadami przebiegniemy biblioteki, jakiegoż musimy dokonać spustoszenia! Biorąc do ręki jakiś tom, traktujący np. o teologii albo szkolnej metafizyce, zapytujemy: Czy zawiera jakieś rozumowanie abstrakcyjne, dotyczace wielkości lub liczby? Nie. Czy zawiera jakieś oparte na doświadczeniu rozumowanie dotyczace faktów i istnienia? Nie. A więc w ogień z nim, albowiem nie może zawierać nic prócz sofisterii i złudzeń!?

Nowi Filozofowie byli równie krytyczni względem schlebiania pismom greckim i łacińskim. Nie gardzili językiem ojczystym: Kartezjusz, Rousseau i Wolter swoje doniosłe prace pisali po francusku; Bacon, Hobbes, Locke i Hume - w języku angielskim; Lessing i Kant - w niemieckim. Krytykowali ponadto pedantyczne podejście do nauczania literatury klasycznej: Kartezjusz - w Rozprawie o metodzie; Locke - w Myślach o wychowaniu; i Rousseau, który opłakiwał dwa lata spędzone by „wypchać sobie głowy łaciną oraz wszelakim innym rupieciem"3. Prowadzeni przez Bacona i Hobbesa, z poparciem Royal Society w Londynie, u schyłku siedemnastego stulecia krytycy ostatecznie przypuścili atak zarówno na cycerońskie, jak i scholastyczne teorie retoryczne i rozwinęli uproszczone podejście do retoryki, bazujące na odrzuceniu wszystkich sztuczności czy to przynależnych do scholastycznych abstrakcji, czy klasycznych formuł. W osiemnastowiecznej Anglii działalność ta przyczyniła się do redukcji retoryki z rozwiniętej, pięcioczęściowej definicji Cycerona do samej formy i stylu ekspresji ${ }^{4}$. Tym

2 D. Hume, An Inquiry Concerning Human Understanding, w: The Philosophical Works of David Hume, Edinburgh: Adam Black and William Tait, 1826 [cyt. za D. Hume, Badania dotyczace rozumu ludzkiego, przeł. J. Łukasiewicz, K. Twardowski, Warszawa: Państwowe Wydawnictwo Naukowe 1977, t. 2, s. 200].

${ }^{3}$ R. Descartes, Discourse on the Method, w: Philosophical Works of Descartes, pkt 1 [R. Descartes, Rozprawa o metodzie, przeł. T. Boy-Żeleński, Warszawa: Wydawnictwo Zielona Sowa 2004]; J. Locke, Some Thoughts Concerning Education, w: The Works of John Locke, Aalen, W.Ger.: Scientia Verlag, 1963, sekcja 168-169 [J. Locke, Myśli o wychowaniu, przeł. M. Heitzman, Warszawa: Wydawnictwo Akademickie „Żak” 2002]; J. J. Rousseau, Confessions in Oeuvres complètes, cz. 1, księga 1, s. 12 [cyt. za J. J. Rousseau, Wyznania, przeł. T. Boy-Żeleński, Warszawa: Państwowy Instytut Wydawniczy 1956, część I, str. 73].

${ }^{4}$ W. S. Howell, Logic and Rhetoric in England, 1500-1700, Princeton, N.J.: Princeton University Press 1956, ss. 388-390; tenże, Eighteen-Century British Logic and Rhetoric, Princeton, N.J.: Princeton University Press 1971, ss. 76, 145 i nast.; K. R. Wallace, Francis Bacon on Understanding, Reason, and Rhetoric, "Speech Monographs" 38 (1971), s. 79-91; 
samym unieważniony został mariaż elokwencji i mądrości. Ci zwolennicy Nowej Filozofii zasadniczo odrzucili oratorską koncepcję edukacji liberalnej - przejęcia tradycji wielkiej i pięknej manifestacji prawdy i cnoty obywatelskiej.

W konsekwencji takiego nastawienia, bez względu na podejmowane w połowie siedemnastego wieku wysiłki na rzecz reformy, jak te Samuela Hartliba, Johna Miltona i ich niewielkiego otoczenia, wolnomyśliciele, eksperymentatorzy, moderniści i philosophes pracowali w zasadzie poza instytucjami edukacyjnymi. Aż do schyłku siedemnastego wieku uczeni zazwyczaj prowadzili badania w pojedynkę, rozproszeni wraz ze swoimi pomocnikami w prywatnych pracowniach i domach. $\mathrm{Z}$ czasem zaczęto zakładać formalne instytucje wspierające te wysiłki, odrębne od uniwersytetów, będące formą towarzystw naukowych poświęconych Nowej Filozofii. Do instytucji tych zalicza się Royal Society w Londynie z 1660 roku $^{5}$, French Académie des Sciences z 1666 roku, a następnie berlińskie Societas Regia Scientarum. Niedługo później powstały darmowe czasopisma publikujące ich osiągnięcia. W roku 1682 Leibniz założył w Lipsku Acta Eruditorum, zaś Holandia, kraj tolerancyjny i z tej racji matka nowych inicjatyw, dała początek kolejnym. Te siedemnastowieczne wysiłki stały się wzorcami dla podobnych przedsięwzięć podejmowanych w osiemnastym i dziewiętnastym stuleciu ${ }^{6}$.

W międzyczasie uniwersytety podupadły. Od początku osiemnastego wieku plaga sofistycznej scholastyki opanowała trzydzieści dwa uniwersytety Świętego Cesarstwa Rzymskiego. Nadzieja na przyszłe reformy leżała w powstaniu uniwersytetów w Halle (1694), Getyndze (1734) i Erlangen (1743) 7 .

P. France, Rhetoric and Truth in France: Descartes to Diderot, Oxford: Oxford University Press 1972.

5 Od tłumaczy: w oryginale autor podaje błędną datę $1622 \mathrm{r}$.

${ }^{6}$ S. d'Irsay, Histoire des universités français et étrangères des origines à nos jours, Paris: Éditions Auguste Picard 1933-35, cz. 2, ss. 56-57, 89-90; M. Ornstein, The Role of Scientific Societies in the Seventeenth Century, Chicago: University of Chicago Press 1938, rozdz. 3-7; M. B. Hall, The Scientific Renaissance, 1450-1630, New York: Harper and Row 1962, rozdz. 7; K. Müller, Zur Entstehung und Wirkung der wissenschaftlichen Akademien und gelehrten Gessellschaften des 17. Jahrhunderts, w: H. Rössler, G. Franz (red.), Universität und Gelehrtenstand 1400-1800, Limburg an der Lahn, W. Ger.: C.A. Starke 1970, ss. 127-143.

${ }^{7}$ N. Hammerstein, Zur Geschichte der Deutschen Universität im Zeitaler der Aufklärung, w: H. Rössler, G. Franz (red.), dz. cyt., ss. 145-172; R. S. Turner, University Reformers and Professional Scholarship in Germany, 1760-1806, w: L. Stone (red.), The University in Society, Princeton, N.J.: Princeton University Press 1974, ss. 495-532; Ch. E. McClelland, The Aristocracy and University Reform in Eighteen Century Germany, w: L. Stone (red.), Schooling and 
Francuskie doświadczenia nie ukształtowały się odmiennie ${ }^{8}$. Pewne przejawy otwartości na Nową Filozofię pojawiły się w Anglii przed restauracją monarchii w 1660 roku, jednak do dziewiętnastego stulecia Oxford i Cambridge zdążyły powrócić do oschłej, scholastyczno-humanistycznej tradycji. Tym sposobem uniwersytety odsuwały się od pracy naukowej angielskich uczonych, których odsetek ukończenia angielskich uniwersytetów stale spadał w ciągu osiemnastego stulecia, ale również od najlepszych klasycznych studiów, w których postępy pozostawały niezwiązane ze studiami uniwersyteckimi ${ }^{9}$. Ocena ta nie oznacza, że Anglia czy Europa były równo podzielone na frakcję „starożytnych” i ,nowożytnych”. Tego rodzaju dychotomia może, rzecz jasna, zostać łatwo poddana krytyce, jak to zresztą miało miejsce ${ }^{10}$. Zarazem jednak uzasadniona jest generalizacja, zgodnie z którą ożywienie i odrodzenie krytycznej filozofii spekulatywnej w początkach nowożytności miało miejsce poza uniwersytetami i realizowaną przez nie tak zwaną ,edukacją liberalną".

Głównej przyczyny takiego stanu rzeczy upatrywać można w poglądzie Spinozy, zgodnie z którym eklezjalna kontrola nad instytucjami edukacyjnymi ograniczała wolność intelektualną, ponieważ credo teologiczne nie skłaniało duchownych do wątpienia. Nie żeby uczeni chcieli w tym względzie wątpić. Wielu, jak Newton czy Boyle, szczerze przyjęło wiarę i mocno wierzyło, że rozum i nauka były całkowicie zharmonizowane z prawdami

Society: Studies in the History of Education, Baltimore: Johns Hopkins University Press 1976, cz. 1, ss. 153-154; tenże, State, Society, and University in Germany, 1700-1914, Cambridge: Cambridge University Press 1980, pkt 1, 2; R. J. Evans, German Universities after the Thirty Years War, "History of Universities" 1 (1981), s. 169-189.

8 S. d'Irsay, dz. cyt. ss. 90-103, 112-142; B. Lésnodorski, Les universités au siècle des lumières, "Commission" (1967), ss. 143-159; J. Le Goff, La conception française de l'université à l'époque de la Renaissance, "Commission" (1967), ss. 94-100; L. B. Brockliss, Philosophy Teaching in France, 1600-1740, "History of Universities" 1 (1981), ss. 131-168.

9 M. L. Clarke, Greek Studies in England, 1700-1830, Cambridge: Cambridge University Press 1945, rozdz. 3; tenże, Classical Education in Britain, 1500-1900, Cambridge: Cambridge University Press 1959, ss. 68-73; N. Hans, New Trends in Education in the Eighteenth Century, London: Routledge and Kegan Paul 1951, ss. 31-36; H. F. Kearney, Scholars and Gentlemen: Universities and Society in Pre-Industrial Britain, 1500-1700, London: Faber and Faber 1970, ss. 141 i nast., 157 i nast.; W. S. Howell, Eighteen-Century, rozdz. 1.

${ }^{10}$ Por. R. F. Jones, Ancients and Moderns: A Study of the Rise of the Scientific Movement in Seventeenth-Century England, wyd. 2, St. Louis: Washington University Press 1961; A. G. Debus, Science and Education in Seventeenth Century: The Webster-Ward Debate, New York: American Elsevier 1970. Zob. również H. F. Kearney, dz. cyt., rozdz. 10. 
wiary - pogląd, który finalnie doprowadził do deizmu ${ }^{11}$. Jednakże od napiętnowania Galileusza, a nawet przed potępieniem Spinozy zarówno przez Żydów, jak i chrześcijan, po sprzeciw biskupa Stillingfleeta względem Locke'a i dalej, duchowieństwo okopało się przeciwko Nowej Filozofii. Opór ten został przeniesiony do szkół gramatycznych i uniwersytetów, o których niezliczone instancje, tworząc ogólną ocenę tego okresu, przyznają, że program kształcenia, struktura instytucjonalna i pedagogika pozostawały w stanie stagnacji czy zmurszenia przez szesnaste, siedemnaste i większość osiemnastego stulecia.

Pomimo takiego osłabienia opór uniwersytetów bynajmniej nie był pasywny. Okazały się one wystarczająco wytrzymałe, by wesprzeć kościoły w ich zdecydowanym potępieniu Nowej Filozofii i wolnomyślicieli, choć jest to tradycyjna interpretacja, która była kwestionowana. Tak jak obecność Newtona w Cambridge wykorzystywano do wsparcia opozycyjnych argumentów, tak oficjalna sankcja nałożona na kartezjańskie dzieła na przełomie osiemnastego stulecia była chwalona lub odrzucana, zależnie od stopnia spróchnienia przypisywanego uniwersytetom. Tego samego rodzaju sprzeczne interpretacje stwierdzić można w odniesieniu do Rozważań dotyczacych rozumu ludzkiego Locke'a, które były znane i czytane przez studentów i kadrę w Oxford i Cambridge, choć zdążyły już zostać objęte zakazem nauczania.

Poza kwestiami dotyczącymi programu kształcenia, podobnie niejednoznaczna okazuje się rola rozmaitych intelektualnych prądów w uniwersytetach. W drugiej połowie siedemnastego wieku platonicy z Cambridge zaatakowali materializm Hobbesa i mechanicystyczny racjonalizm Kartezjusza, a co stąd wynika - matematyczno-mechanicystyczny model świata. Platonicy z Cambridge bronili poglądu spirytualistów na kosmos jako podstawy moralności chrześcijańskiej. W związku z tym można by ich zakwalifikować jako krytyków Nowej Filozofii. Jednakże są oni również charakteryzowani jako umiarkowani i ,latitudarianie" - względnie tolerancyjni i otwarci chrześcijanie tej epoki, którzy utrzymywali, że postulaty rozumu i wiary są całkowicie zgodne. W następnym stuleciu filozofowie szkockiego Common

${ }^{11}$ E. Cassirer, The Philosophy of the Enlightenment, przeł. F. C. A. Koelln, J. P. Pettegrove, Princeton, N.J.: Princeton University Press 1951, ss. 39-45; S. Hampshire, Spinoza, Harmondsworth, Eng.: Penguin 1951, ss. 42-44, 200-209; G. R. Cragg, The Church and the Age of Reason, 1648-1789, Harmondsworth, Eng.: Penguin 1960, ss. 74-78; K. Martin, French Liberal Thought in the Eighteen Century: A Study of Political Ideas from Bayle to Condorcet, red. J. P. Mayer, wyd. 2, London: Phoenix 1962, ss. 123-131; A. R. Hall, The Scientific Revolution, 1500-1800: The Formation of the Modern Scientific Attitude, wyd. 2, London: Longmans Green 1962, ss. 103-105. 
Sense zdecydowanie sprzeciwiali się sceptycyzmowi Berkeley'a i Hume'a, utrzymując, że filozofia musi być ugruntowana na pewnych założeniach dotyczących świata, które są wspólne wszystkim ludziom i uznane za prawdziwe. Członkowie szkoły Common Sense, tacy jak Thomas Reid i George Campbell, sprawowali honorowe urzędy na szkockich uniwersytetach, zaś ich sprzymierzeniec, James Beattie, otrzymał emeryturę od króla i doktorat z uniwersytetu Oxford za ataki na najbardziej krytyczne i powierzchowne polemiki Hume'a. Z drugiej strony, Reid i Campbell przyczynili się do oderwania studiów nad logiką tak od scholastyki, jak i humanistycznej retoryki i do połączenia ich z badaniami naukowymi. Reid zaś postrzegany jest jako umiarkowany, którego frakcja utorowała drogę Oświeceniu.

Pomimo takich dwuznaczności ostatecznie stwierdzić należy, że uniwersytety na ogół sprzeciwiały się wolności myśli i nowej edukacji (new learning). Propozycje reform nie pochodziły z samych uniwersytetów, nawet jeśli niektórzy członkowie wydziałów uznawali zalety Nowej Filozofii ${ }^{12}$. Jeszcze w roku 1765, gdy Cambridge zdawał się dystansować Oxford pod względem osiągnięć naukowych i matematycznych, biskup anglikański Richard Watson mógł dalej ubiegać się o profesurę z chemii, choć, jak później stwierdził, nie wiedział nic na temat chemii i nigdy nie otrzymał żadnego przeszkolenia w tej dziedzinie.

Wyjątki istniały, by wskazać pewne włoskie uniwersytety, które jako pierwsze uwzględniły niektóre elementy nowej edukacji ${ }^{13}$. Przywództwo

12 Joseph Priestley, podobnie jak inni przedstawiciele nowej nauki i filozofii, wydaje się popierac takie stanowisko. Zob. J. Priestley, An Examination of Dr. Reid's „Inquiry into the Human Mind on the Principles of Common Sense”, Dr. Beattie's „Essay on the Nature and Immutability of Truth”, and Dr. Oswald's „Appeal to Common Sense on Behalf of Religion”, wyd. 2, London: J. Johnson, 1775. Na temat zróżnicowanych interpretacji intelektualnego klimatu uniwersytetów por. M. L. Clarke, Classical, ss. 65-69; G. R. Cragg, dz. cyt., ss. 68-78; F. C. Copleston, A History of Philosophy, Westminster, Md.: Newman 1962, cz. 5, rozdz. 3, 17 [F. Copleston, Historia filozofii. Od Hobbesa do Hume 'a, przeł. S. Zalewski, Warszawa: Instytut Wydawniczy PAX, 2009]; P. Gay, The Enlightenment: An Interpretation, New York: Alfred A. Knopf 1969, ss. 24-25, 155-158; V. H. Green, The Universities: British Institutions, Baltimore: Penguin 1969, ss. 41-42, 232-236; J. D. Hoeveler, Jr., James McCosh and the Scottish Intellectual Tradition: From Glasgow to Princeton, Princeton, N.J.: Princeton University Press 1981, rozdz. 4.

${ }^{13}$ O dalszej dyskusji na temat nowej edukacji na uniwersytetach i Dissenting Academies piszę korzystając z tekstów: S. d'Irsay'a, dz. cyt., ss. 1-23; M. L. Clarke, Classical, rozdz. 11; V. L. Bullough, Educational Conflict and the Development of Science in the Renaissance, "Bucknell Review" 15 (1967), ss. 35-45; V. H. Green, dz. cyt., rozdz. 5; K. A. Sprengard, Die Bedeutung der Artistenfakultät für die Entwicklung der modernen Philosophie des XIV. 
objęły wówczas, co było przewidywalne, uniwersytety w Holandii, gdzie neutralność w polityce i religii podtrzymywano w celu wspierania handlu. Te z kolei okazały się częściowo odpowiedzialne za wzbudzenie zainteresowania Nową Filozofią w uniwersytetach w Szkocji po restauracji monarchii w 1660 roku i jego wzrost po Rewolucji roku 1689. Rekrutacja na uniwersytety w Szkocji była mniej arystokratyczna i dopuszczała więcej chłopców pochodzących z klasy średniej i ubogiej niż w Anglii, w efekcie czego odsetek angielskich naukowców, którzy ukończyli szkockie uniwersytety stopniowo wzrastał w ciągu osiemnastego stulecia. Lecz nawet w tym stosunkowo postępowym środowisku, zainteresowanie Nową Filozofią wywarło stosunkowo niewielki wpływ na program nauczania sztuk wyzwolonych. Pierwszy rok poświęcony był nauce gramatyki łacińskiej i greckiej oraz literaturze bazującej na sztuce oratorskiej i retorycznej. Drugi rok zawierał rozwinięcie tych przedmiotów poszerzone o naukę logiki i podstaw matematyki. Trzeci poświęcony był dalszemu powtarzaniu oraz elementom etyki, zaś czwarty ocenie studentów oraz odrobinie filozofii i metafizyki.

Szkockie i holenderskie uniwersytety wywarły przemożny wpływ na kolejną grupę wyjątków, Dissenting Academies, które cieszyły się reputacją zapewniających najbardziej nowoczesną i postępową edukację spośród dostępnych w Anglii. W rzeczy samej pewien historyk mówi o „nasieniu nowoczesnej edukacji liberalnej”, zasianym przez Dissenting Academies w żyznej glebie „liberalizujących idei” szkockich i holenderskich edukatorów ${ }^{14}$. Przyczyniły się do tego wpływy purytańskie, jak choćby w przypadku Samuela Hartliba, nawet jeśli jego własna akademia upadła. Pomimo tego w toku początkowego okresu zakładania akademii pomiędzy rokiem 1670 i 1720 zwolennicy Dissenting Academies w znacznym stopniu powielili model realizowany w Oxford i Cambridge, z których zostali wykluczeni. W osiemnastym wieku jedynie matematyka i nauki eksperymentalne zdołały stopniowo zająć miejsce w programach nauczania tych akademii, lecz nawet wtedy te liberalno-wolnościowe (liberal-free) przedmioty nie były rozpatrywane jako

und XV. Jahrhunderts, “Actes” (1969), ss. 691-699; H. F. Kearney, dz. cyt., ss. 129-135, 156; J. D. Hoeveler, dz. cyt., rozdz. 2.

${ }^{14}$ N. Hans, dz. cyt., s. 57. Więcej na temat Dissenting Academies zob. H. McLachlan, English Education Under the Test Acts, Being the History of the Non-conformist Academies, 1662-1820, Manchester, Eng.: Manchester University Press 1931, ss. 19-32; R. L. Greaves, The Puritan Revolution and Educational Thought: Background for Reform, New Brunswick, N.J.: Rutgers University Press 1969, s. 92; V. H. Green, dz. cyt., ss. 44-47, 228-232; Ch. Webster, Samuel Hartlib and the Advancement of Learning Cambridge: Cambridge University Press 1970, ss. 7-10, 71-75. 
element „edukacji liberalnej”. Fakt ten odzwierciedla ambiwalencję w perspektywie przyjętej w nawet najbardziej „oświeconych” jednostkach wyższej edukacji w Anglii tego okresu. Dopiero w drugiej połowie osiemnastego stulecia rozpoczęło się „subtelne, acz zauważalne przesunięcie” w kwestii znaczenia edukacji ,liberalnej”"15.

Niewielka lub nawet żadna zmiana dokonała się w pozostałych angielskich instytucjach edukacyjnych. Wykłady uniwersyteckie oparte na nowej edukacji, które mogły zostać wprowadzone, nigdy nie zostały objęte oficjalnym pozwoleniem. Kształcenie w zakresie przedmiotów liberalno-wolnościowych było raczej oferowane prywatnie za opłatą aniżeli wspierane przez finanse uczelni. Sytuacja Gresham College odzwierciedla ponadprogramowy charakter tych przedmiotów. Choć czasami stawiany jako wzór dla profesorów nauczających Nowej Filozofii na Oxford i Cambridge, Gresham nie oferował żadnych stopni i był usytuowany w Londynie $\mathrm{z}$ dala od programów sztuk wyzwolonych realizowanych na tych dwóch uniwersytetach. W przeciwieństwie do tego Directions for Younger Scholars, autorstwa Thomasa Barlowa, nauczyciela z Oxfordu w drugiej połowie siedemnastego stulecia, prezentują połączenie scholastycznych i humanistycznych studiów rzeczywiście obecnych w tej instytucji, podobnie jak w dziele Of Education Especially of Young Gentleman (1673), autorstwa Obadiaha Walkera, który również uczył w Oxford. Późniejsze sprawozdanie ze standardowego kursu dżentelmena, przedrukowane co najmniej sześć razy do 1699 roku, zawierało krytykę nadmiernego entuzjazmu dla nauki, jednocześnie definiując „,wolność ducha" bardziej jako wielkoduszność niż wolność od przymusu ${ }^{16}$.

Podejście nauczycieli bardzo zbliżone do tego, które stulecie wcześniej w swojej edukacji odebrał Sir Philip Sidney, przeniesiono do społeczeństwa georgiańskiego, gdzie „liberalny” implikował dworskość, zaś „sztuki wyzwolone" oznaczały edukację dżentelmena. Kiedy w opozycji do dwóch uniwersytetów ustanowiono niezależne akademie i inkorporowano do nich

15 S. Rothblatt, Tradition and Change in English Liberal Education: An Essay in History and Culture, London: Faber and Faber 1976, ss. 27, 76, 98 i nast.

16 Stanowisko Barlowa i Walkera omawia H. F. Kearney, dz. cyt., ss. 146-159. Tu i poniżej korzystam z J. W. Adamson, Pioneers of Modern Education, 1600-1700, Cambridge: Cambridge University Press 1921, rozdz. 10; N. Hans, dz. cyt., ss. 63-67, 117-121; J. L. Mahoney, The Classical Tradition in Eighteen Century English Rhetorical Eduaction, "History of Education Journal" 9 (1958), s. 95; F. Caspari, Humanism and the Social Order in Tudor England, Chicago: University of Chicago Press 1954; New York: Teachers College Press 1968, s. 299; P.-A. Lee, Some English Academies: An Experiment in the Education of Renaissance Gentleman, "HEQ" 10 (1970), ss. 273-286; S. Rothblatt, dz. cyt., s. 25, rozdz. 3, 6, 7. 
przedmioty ścisłe i nowoczesne języki, ich „edukacja liberalna” w dalszym ciągu bazowała na klasycznych tekstach Cycerona i Arystotelesa. W tym czasie ufundowano inne „dworskie akademie”, a college'e przy uniwersytetach stały się nawet bardziej ekskluzywne społecznie. W roku 1721 Nathan Bailey opublikował pierwsze wydanie An Etymological English Dictionary (który do roku 1802 doczekał trzydziestu wydań, podobnie jak niemieckie tłumaczenie) i wyraźnie powiązał „edukację liberalną” ze społeczeństwem, dla którego wartością jest uprzejmość. Pogląd ten został powtórzony w drugiej połowie osiemnastego stulecia przez Vicesimusa Knoxa, członka St. John's College w Oxfordzie, którego Liberal Education: Or, a Practical Treatise on the Methods of Acquiring Useful and Polite Learning do roku 1795 roku miała jedenaście wydań. Knox pisał:

W blasku ducha innowacji i reform... oni (Milton, Locke, Rousseau oraz ... inni, którzy pisali na ten temat) krytykują sposoby leczenia, które są właściwe, rekomendują metody, których nie da się użyć w praktyce, i które, gdyby mogli, stałyby się bezużyteczne czy zgubne. ... Mam tedy na uwadze w powyższym traktacie, aby przemawiać na korzyść tego starożytnego systemu edukacji, który składa się z klasycznych dyscyplin i który wytworzył w naszym narodzie wiele upiększeń w ludzkiej naturze ${ }^{17}$.

W początku XIX stulecia oxfordzkie statuty dla stopnia bakałarza wymagały, by ,zawsze i dla każdego stopnia było podejmowane studiowanie literatury humanistycznej, w tym szczególnie greckich i rzymskich pisarzy, spośród których trzeba uwzględnić co najmniej trzech z najwyższej klasy". Uwaga poświęcona Humanae Literatures wskazuje w istocie na wzmożone zainteresowanie studiami klasycznymi, które nastąpiło w tym czasie zarówno w Oxfordzie, jak i w Cambridge. Równocześnie niemieckie uniwersytety rozwijały ideę neohumanistycznych studiów, ale „humanizm” zaistniał najpierw jako termin angielski, akcentujący literaturę grecką i łacińską, w przeciwieństwie do bardziej użytecznego i ścisłego kształcenia ${ }^{18}$. Na niższych

17 V. Knox, Liberal Education; Or, a Practical Treatise on the Methods of Acquiring Useful and Polite Learning, London: Charles Dilly 1789, cz. 1, ss. 1-3; W. E. Axon, English Dialect Words of the Eighteen Century as Shown in the ,Universal Etymological Dictionary” of Nathaniel Bailey, London: Trübner 1883, ss. v-viii.

18 Zob. M. L. Clarke, Classical, ss. 98, 104-131; R. Klibansky, Questions et discussions, “Actes" (1969), ss. 301-302; C. Diehl, Americans and German Scholarship, 1770-1870, New Haven: Conn.: Yale University Press 1978, rozdz. 1; Ch. E. McClelland, State, Society, 
szczeblach edukacji w Anglii była podobna sytuacja, co widać w znanym orzeczeniu sądowym z roku 1805, według którego w odniesieniu do tradycyjnego i współczesnego użycia „Grammar School” oznaczało szkolę „,nauczającą gramatyki języków obcych" i z tego względu jej nauczyciel nie miał uprawnień do nauczania języka ojczystego. Nic dziwnego, że po dokonaniu przeglądu modeli programów nauczania w roku 1828 władze uniwersytetu w Yale skonkludowały, że „na Wyspach Brytyjskich, we Francji, Niemczech, Włoszech i, w istocie, w każdym kraju, w którym literatura nabyła wyróżnienia i wagi, klasyczne dzieła greckie i rzymskie tworzą zręby edukacji liberalnej"19.

Fakt, że college'u w New Haven należy poszukiwać w rzędzie liderów edukacji wzdłuż Atlantyku, stanowi ilustrację wczesnego rozwoju amerykańskich college'ów. Mówię to, ponieważ, optując za bardziej tradycyjną interpretacją dotyczącą wejścia do brytyjskiej edukacji nauk eksperymentalnych i „nowoczesnych” przedmiotów - jako topornych i niepewnych przyczynków dla formującego się ideału liberalno-wolnościowego, mam szczerą obawę przez podpisywaniem się pod rewizjonistycznymi czy nowoczesnymi interpretacjami historii amerykańskiej edukacji niższego szczebla, które odnotowały w ostatnich dekadach wzrost popularności. Pomimo tego przyznać należy, że przedmioty ścisłe nie zostały całkowicie wykluczone z dziewięciu college'ów założonych w okresie kolonialnym, każdy przez dominujący w danym miejscu odłam religijny: Harvard (1636) przez Kościół kongregacjonalistyczny; William and Mary (1693) - anglikański; Yale (1701) kongregacjonalistyczno-prezbiteriański; Princeton (1746) - prezbiteriański; Columbia (1754) - anglikański; Pennsylvania (1755) - anglikańsko-prezbiteriański; Brown (1765) - baptystyczny; Rutgers (1766) - Holenderski Reformowany; Dartmouth (1769) - Kościół kongregacjonalistyczny.

W roku 1711 William i Mary ustanowili pierwszą katedrę matematyki i filozofii naturalnej w Ameryce, a do roku 1776 pięć kolejnych college'ów poszło ich śladem. Harvard mianował Isaaca Greenwooda, który przyniósł ze sobą Newtonowską perspektywę zawartą w A Course in Experimental Philosophy, a następnie Johna Winthropa, który nauczał przez cztery dekady jako drugi profesor matematyki i filozofii naturalnej. W Yale wysiłki poczy-

ss. 99-131; M. McMackin Garland, Cambridge before Darwin: The Ideal of a Liberal Education, 1800-1860, Cambridge: Cambridge University Press 1980, rozdz. 1.

19 Reports on the Course of Instruction in Yale College by a Committee of the Corporation and the Academical Faculty, New Haven: Conn.: Hezekiah Howe 1828, s. 34; The AttorneyGeneral v. Whiteley, July 20th, 22d, 180511 Vasey Junior 241. 
nione w tym samym kierunku zainicjowane zostały przez Samuela Johnsona, nauczyciela w latach 1716-1719, i rozszerzone przez kierującego Yale Thomasa Clapa i innych w latach poprzedzających Rewolucję ${ }^{20}$.

W odniesieniu do College of New Jersey, funkcjonującego później pod nazwą Princeton, zaznaczyły się dwa nurty wpływające na wszystkie kolonialne college'e, a zwłaszcza na college prezbiteriański. Z jednej strony Wielkie Przebudzenie i turbulencja wywołana przez głosicieli odnowy religijnej, które, pomijając stopień antyintelektualizmu, wspierało pluralizm i edukacyjną różnorodność z racji swoich tendencji schizmatycznych, $\mathrm{z}$ drugiej strony aktywność Dissenting Academies i szkockich uniwersytetów, których relatywna sympatia do przedmiotów liberalno-wolnościowych została już uprzednio wspomniana. Jakkolwiek czterech pierwszych kierujących uczelnią trzymało się ściśle scholastyczno-humanistycznej orientacji studiów, a programy kształcenia nie były rozszerzone aż do czasu kadencji Johna Witherspoona (1768-1794), to czynniki te miały wpływ na Princeton. W roku 1771 ustanowiono tam profesurę z zakresu matematyki i filozofii naturalnej, a programy nauczania w kolejnym roku uwzględniały geografię, astronomię i język francuski. W tym czasie Rutgers, utworzony jako Queen's College w roku 1766, raczej ściśle przestrzegał modelu wypracowanego przez sąsiadujące New Jersey ${ }^{21}$.

${ }^{20}$ R. F. Butts, The College Charts Its Course: Historical Conceptions and Current Proposals, New York: McGraw-Hill 1939, ss. 60-66; Th. Hornberger, Scientific Thought in the American College, 1638-1800, Austin: University of Texas Press 1945, ss. 25-26, 44-51; C. A. Hangartner, Movements to Change American College Teaching, 1700-1830 (rozprawa doktorska), Yale University 1955, ss. 128-136; R. Warch, School of the Prophets: Yale College, 1701-1740, New Haven, Conn.: Yale University Press 1973, ss. 72, 195, 214-215; B. M. Kelley, Yale: A History, New Haven, Conn.: Yale University Press 1974, ss. 70-82.

${ }^{21}$ Th. J. Wertenbaker, Princeton, 1746-1896, Princeton, N.J.: Princeton University Press 1946, rozdz. 3; C. A. Hangartner, dz. cyt., ss. 48-63; G. P. Schmidt, Princeton and Rutgers: The Two Colonial Colleges of New Jersey, Princeton, N.J.: D. Van Nostrand 1964, s. 34; R. P. McCormick, Rutgers: A Bicentennial History, New Brunswick, N.J.: Rutgers University Press 1966, rozdz. 1; D. Sloan, The Scottish Enlightenment and the American College Ideal, New York: Teachers College Press 1971, ss. 33, 64-72, 110-112; tenże, Harmony, Chaos, and Consensus: The American College Curriculum, "Teachers College Record" 73 (1971), ss. 227-232; tenże, The great Awakening and American Education: A Documentary History, New York: Teachers College Press 1973, ss. 19-27, 41, 128; D. C. Humphrey, Colonial Colleges and English Dissenting Academies: A Study in Transatlantic Culture, "HEQ" 12 (1972), ss. 184-187; H. Miller, The Revolutionary College: American Presbyterian Higher Education, 1707-1837, New York: New York University Press 1976, rozdz. 1, s. 94. 
W Columbia, ufundowanym jako King's College, wpływ nowej edukacji zaznacza się zarówno w tekstach odzwierciedlających filozofię Kartezjusza i Locke'a, jak i w stopniowym włączaniu „obserwacji i eksperymentu” w zakres filozofii naturalnej ${ }^{22}$. Jeszcze więcej uznania dla edukacyjnej innowacji zwykle przypisuje się założonej w Filadelfii College, Academy and Charitable School. Na to uznanie mają wpływ związki college'ów z Benjaminem Franklinem, którego Proposals Relating to the Education of Youth in Pensylvania z 1979 roku przekonywały za programową użytecznością i zastosowaniem „Apparatus for Experiments in Natural Philosophy” i którego Idea of the English School z roku 1751 jest często cytowana ze względu na swój sprzeciw wobec klasycznych wpływów oraz propagowania badań w języku ojczystym. Co więcej, William Smith, który został nazwany pierwszym rektorem, napisat A General Idea of the College of Mirania, co przypominało zreformowany kierunek studiów w szkockich uniwersytetach i wcieliło wiele elementów Oświeceniowego myślenia edukacyjnego. Kolejny dowód otwartości na nową edukację odnaleźć można w rozpoczęciu „Exercises” w Pensylvanii i w późniejszym powołaniu Benjamina Rusha na pierwszego profesora chemii w Ameryce ${ }^{23}$.

Powyższe uwagi dają ogólną charakterystykę dowodów przedstawianych celem ukazania że „Nowa Edukacja dała o sobie znać w całym [kolonialnym] programie nauczania wyróżniającym indukcję kosztem dedukcji, etykę kosztem teologii oraz język angielski kosztem łaciny”. Interpretacjom tym często towarzyszyły zapewnienia, że kadra nauczająca stała się bardziej wyspecjalizowana i sprofesjonalizowana i że scholastyczne dysputy ustąpiły miejsca jurydycznym debatom w języku angielskim ${ }^{24}$. Obecnie wszystkie

${ }^{22}$ D. C. Humprey, From King's College to Columbia, 1746-1800, New York: Columbia University Press 1976, ss. 164-180.

${ }^{23}$ B. Franklin, Proposals Relating to the Education of Youth in Pennsylvania, Philadelphia: B. Franklin 1749, ss. 6-9, 13-14; Idea of the English School sketched out for the Consideration of the Trustees of the Philadelphia Academy Franklina dołączona do A Sermon on Education, Wherein Some Account Is Given of the Academy Established in the City of Philadelphia Wielebnego Richarda Petersa, Philadelphia: Franklin and Hall 1751, ss. 1-8; E. P. Cheyney, History of the University of Pennsylvania, 1740-1940, Philadelphia: University of Pennsylvania Press 1940, ss. 28-29; T. W. Smith, 'Exercises' Presented during the Commencements of the College of Philadelphia and Other Colonial Colleges, "PH" 7 (1967), s. 182-222; L. F. Snow, The College Curriculum in the United States, New York: Bureau of Publications, Teachers College, Columbia University 1907, rozdz. 3, 4 (Snow znacznie przecenia wpływ eseju Williama Smith'a, ale zarazem ułatwia śledzenie kierunków oddziaływań).

${ }^{24}$ Cytowanie za: F. Rudolph, Curriculum: A History of the American Undergraduate Course of Study Since 1636, San Francisco: Jossey-Bass 1977, ss. 37; J. J. Walsh, Education 
tego rodzaju zmiany są przyjęte i z dzisiejszej perspektywy tym szczególnym pytaniem, które trzeba zadać, jest: czy nowa edukacja była rzeczywiście uważana za część „edukacji liberalnej”? Przyjdzie czas, aby rozważyć ten punkt, ale jeszcze nie w tym miejscu, ponieważ - w przeciwieństwie do wrażenia pozostawionego przez modernistycznych interpretatorów - Nowa Filozofia i Oświecenie miały raczej niewielki wpływ na kolonialne college'e. Pozostawały one silnie odizolowane od ożywienia tradycji filozoficznej, jak gdyby stanowiły scholastyczno-humanistyczną tradycję przystosowaną do chrześcijańskich celów.

Różnice w interpretacjach pomiędzy historykami są w dużej mierze kwestią kontekstu. Jak dla przykładu zauważa Frederic Rudolph, student z 1642 roku odnalazłby pewne zmiany w programie nauczania z roku $1764^{25}$. Jednak $\mathrm{w}$ dziedzinie nauk ścisłych $\mathrm{z}$ połowy osiemnastego stulecia nauczający w college'ach nie byli szczególnie biegli, zaś metody nauczania i wyposażenie znajdowały się pod niewielkim wpływem nowych osiągnięć. Podobnie jak w Europie, sprawa oświeconego myślenia miała miejsce poza instytucjami edukacyjnymi.

Największe kolonialne umysły bardzo wcześnie zostały zwerbowane do Royal Society w Londynie, wśród nich było kilku kolonialnych edukatorów, jak Increase Mather czy John Winthrop. Jednakże same college'e dążenie do wiedzy oddały instytucjom zewnętrznym, jak choćby American Philosophical Society, zorganizowanemu przez Benjamina Franklina i połączonemu w roku 1769 z podobną organizacją w Filadelfii celem utworzenia American Philosophical Society Held at Philadelphia for Promoting Useful Knowledge. Dwa lata później Society liczyło 248 członków, Amerykanów i Europejczyków, zaś na przełomie stulecia liczba ta wzrosła do 650, kiedy to w Bostonie została założona American Academy of Arts and Sciences. Były to amerykańskie instytucje przesiąknięte liberalno-wolnościowym etosem Oświecenia ${ }^{26}$. Naukowe i eksperymentalne metody były stosowa-

of the Founding Fathers of the Republic: Scholasticism in the Colonial Colleges, a Neglected Chapter in the History of American Education, New York: Fordham University Press 1935, rozdz. 3; J. W. Kraus, The Development of a Curriculum in the Early American Colleges, "HEQ" 1 (1961), ss. 70-71. Więcej zob. C. A. Hangartner, dz. cyt., rozdz. 1 i 2; S. E. Morison, Three Centuries of Harvard, 1636-1936, Cambridge, Mass.: Belknap 1936, s. 89-90.

${ }^{25}$ F. Rudolph, dz. cyt., s. 53.

26 A. O. Hansen, Liberalism and American Education in the Eighteen Century, New York: Macmillan 1926, ss. 62, 105-107; F. Klassen, Persistence and Change in Eighteen Century Colonial Education, "HEQ" 2 (1962), ss. 92-93; J. C. Kiger, American Learned Societies, Washington, D.C.: Public Affairs Press 1963, rozdz. 1; R. S. Bates, Scientific Societies in the 
ne przez „amatorów”, nie zaś akademickich i profesjonalnych naukowców w college'ach.

Wyjątki obejmowały zazwyczaj profesorów szkół medycznych, którzy stanowili zdecydowaną większość naukowców kształconych poza amerykańskimi koloniami. Istotnie, jedno z krajowych badań przeprowadzonych nad 124 profesorami amerykańskich college'ów spośród 210 nauczających pomiędzy rokiem 1750 i 1800 - wskazuje, że nie wliczając profesorów z zakresu medycyny, jedynie dwóch kształciło się w Europie. Nawet tam, gdzie szkoła medyczna była wybitna, jak w Filadelfii, działalność naukowa obracała się raczej wokół American Philosophical Society aniżeli w ramach college'ów. Z pewnością można było tego oczekiwać w stosunku do miasta Filadelfia będącego siedzibą Society. W tym samym badaniu na 124 profesorów zaledwie piętnastu przynależało do Society, większość spośród College of Philadelphia. Kiedy zaś American Academy of Arts and Sciences i American Academy of Fine Arts także zostały uwzględnione, podniosło to liczbę członków będących profesorami college'ów raptem do dwudziestu czterech $^{27}$.

Pomijając zwykły brak uczestnictwa, college'e wyznaniowe oczerniały nową krytyczną filozofię i metodę eksperymentalną, nawet gdy zaczęły uwzględniać wyniki badań naukowych, które mogłyby zostać włączone w zakres teologii naturalnej. Tym sposobem denuncjacje wysłowione przez college'e przeszły u schyłku siedemnastego wieku i w początkach osiemnastego stulecia od potępienia deizmu i powiązanego $\mathrm{z}$ nim polegania na ludzkiej samodzielności - uzasadniania raczej z pomocą rozumu niż usprawiedliwienia z pomocą wiary - w stronę lęku przed ,niepokonanym sceptycyzmem", który osaczył, dla przykładu, kierującego King’s College Samuela Jacksona w odniesieniu do Johna Locke'a, ale również jego intelektualnych następców. Walter Minto, nowy profesor fizyki i matematyki w Princeton,

United States, Cambridge: MIT Press 1965, ss. 2-12; G. F. Frick, The Royal Society in America, w: A. Oleson, S. C. Brown (red.), The Pursuit of Knowledge in the Early American Republic: American Scietific and Learned Societies from Colonial Times to the Civil War, Baltimore: Johns Hopkins University Press 1976, ss. 70-73; A. Oleson, Introduction: To Build a New Intellectual Order, w: A. Oleson, S. C. Brown (red.), dz. cyt., ss. xv-xxv; J. C. Greene, Science, Learning, and Utility: Patterns of Organization in the Early American Republic, w: A. Oleson, S. C. Brown (red.), dz. cyt., ss. 1-3.

27 Th. Hornberger, dz. cyt., ss. 66-74; W. L. Sachse, The Colonial American in Britain, Madison: University of Wisconsin Press 1956, ss. 55-63; W. D. Carell, American College Professors: 1750-1800, "HEQ" 8 (1968), ss. 291-292; D. Sloan, The Scottish Enlightenment, ss. 226-236. 
próbował łagodzić ten strach w latach osiemdziesiątych osiemnastego wieku. Obawy w dalszym ciągu podtrzymywał Charles Nisbet, kierujący Dickinson College od roku 1800, który odczuwał wstręt wobec ,monstrualnych i zniekształconych wytworów” „ducha wolnych badan"”28.

Od Nowej Anglii do Starego Południa klasyczny program nauczania i jego tradycja utrzymywały się. Rzeczywiście, mamy dowód wskazujący, że klasyczne studia humanistyczne od drugiej połowy osiemnastego wieku rosły w siłę, szczególnie w odniesieniu do belles lettres, sztuki oratorskiej, historii, poezji i literatury - które były skierowane na zaszczepienie poprzez edukację „,noty i moralności”. To, że studia te służyły legitymizowaniu elit zgłębiających wiedzę dla niej samej, dla ozdoby, potwierdza Daniel Calhoun: „Dla wielu [kolonialnych] studentów, być może nawet dla większości, edukacja liberalna nie pełniła żadnej funkcji ani konkretnego użytku dla społeczeństwa. Łacina, greka, filozofia, jak również uczęszczanie do którejś ze szkół wyższych, stanowiły wyznaczniki prestiżu i dobrego wychowania"29. Taka generalizacja nie jest bynajmniej skrajna, zwłaszcza w kontekście jednorodności kolonialnego programu nauczania. Program sztuk wyzwolonych uległ tylko nieznacznym modyfikacjom - od katalogu Thomasa Clapa z roku 1743 do tego z roku 1778 autorstwa Ezry Stiles, czy od Dartmouth w New Hampshire do Uniwersytetu North Carolina (1789), który był pierwszym stanowym uniwersytetem nadającym stopnie naukowe ${ }^{30}$.

Oprócz teologii studenci pierwszego roku prawie cały swój czas poświęcali gramatyce greckiej i łacińskiej, a także arytmetyce. Studenci drugiego roku kontynuowali te studia, poszerzając je o retorykę, w tym być może o literaturę piękną w języku ojczystym, logikę, zaawansowaną arytme-

${ }^{28}$ S. Johnson, Elementa Philosophica: Containing Chiefly, Noetica, Or Things Relating to the Mind or Understanding: and Ethica, or Things Relating to the Moral Behaviour, Philadelphia: B. Franklin and D. Hall 1752, wers 1, s. 6; S. Miller, Memoir of the Rev. Charles Nisbet, D.D., Late President of Dickinson College, Carlisle, New York: J. Leavitt 1840, s. 269.

29 D. H. Calhoun, The Intelligence of a People, Princeton, N.J.: Princeton University Press 1973, s. 40; R. Middlekauf, A Persistent Tradition: The Classical Curriculum in Eighteen Century New England, "William and Mary Quarterly", seria 3, 18 (1961), ss. 56-60; F. Klassen, dz. cyt., ss. 83-99; R. M. Gummere, The American Mind and the Classical Tradition: Essays in Comparative Culture, Cambridge: Harvard University Press 1963, rozdz. 1; E. A. Miles, The Old South and the Classical World, "North Carolina Historical Review" 48 (1971), ss. 258-275; P. Vine, The Social Function of Eighteen-Century Higher Education, "HEQ" 16 (1976), ss. 409-424.

${ }^{30}$ L. F. Snow, dz. cyt., ss. 41-45, 54, 79-82; L. B. Richardson, History of Dartmouth College, Hanover, N.H.: Dartmouth College 1932, cz. 1, ss. 248-249; J. W. Kraus, dz. cyt., ss. 68-75; R. M. Gummere, dz. cyt., rozdz. 4; B. M. Kelley, dz. cyt., ss. 70-83. 
tykę czy algebrę. Studenci trzeciego roku kontynuowali naukę łaciny, greki i retoryki oraz przechodzili przez algebrę, geometrię, a może nawet przez trygonometrię lub jej ,pochodne” równolegle z kursem filozofii naturalnej. Studenci czwartego roku dokonywali powtórki materiału z trzech poprzednich lat, studiowali metafizykę, brali udział w wieńczącym kursie rektorskim poświęconym filozofii moralności oraz, jeśli był na to czas, w okresie wiosennym poszerzali wiedzę z zakresu filozofii naturalnej. Ta uogólniona podstawa programowa studiów była realizowana za pomocą długotrwałej praktyki recytacji i deklamacji wraz z wprowadzanym stopniowo wykładem.

W międzyczasie pierwsza katedra matematyki i filozofii naturalnej w Ameryce, utworzona na William and Mary College, w 1711 roku upadła. Pierwszy profesor, który ją objął, był właściwie tułaczem; drugi prowadził zajęcia przez rok lub dwa, a następnie opuścił Virginię, zachowując przy tym nadal swoje stanowisko. Od tego czasu minęło prawie dwadzieścia lat, a naukowa aktywność w kolonialnym William and Mary College nadal była niewielka. Na Harvardzie profesor Isaac Greenwood nauczał swojej filozofii naturalnej w wymiarze szesnastu wykładów. Jego następca, John Winthrop, w trzydziestu wykładach omawiał dźwignię, koło pasowe, równię pochyłą, śrubę, klin, grawitację, siły przyciągania i kohezji, prawa ruchu, magnetyzm, elektryczność, ciecze, optykę, astronomię oraz inne elementy mechaniki. Nic dziwnego, że szkolenie w naukach ścisłych w osiemnastym stuleciu było częstokroć określane jako „nieco więcej niż ciąg definicji”’”.

W porównaniu z Harvardem Yale pozostawał bardziej konserwatywny teologicznie i edukacyjnie. Dysputy oparte na sylogizmie popularyzowane były w New Haven prawie do roku 1790; pomimo zapewnień o wczesnej obecności Newtona w programie nauczania w Yale, kierujący nim Theodore Dwight Woolsey komentował w połowie dziewiętnastego wieku, że nawet w latach siedemdziesiątych osiemnastego wieku prezentowanie studentom Princypiów Newtona „musiało być bardzo rzadkim wydarzeniem” ${ }^{32}$. Nie inaczej było w przypadku King's College. Kierujący nim Samuel Johnson (1754-1763) opisał w swoich pierwszych komunikatach bardzo szeroki i po-

${ }^{31}$ Cyt. za: E. P. Cheyney, dz. cyt., s. 83; S. M. Guralnick, Science and the Antebellum American College, Philadelphia: American Philosophical Society 1975, s. 14; Th. Hornberger, dz. cyt., ss. 25-51; C. A. Hangartner, dz. cyt., ss. 128-136.

${ }^{32}$ T. D. Woolsey, An Historial Discourse Pronounced before the Graduates of Yale College, August 14, 1850; One Hundred and Fifty Years After the Founding of that Institution, New Haven: B.L. Hamlen 1850, s. 61. Por. R. Warch, dz. cyt., ss. 215-229; B. M. Kelley, dz. cyt., ss. 41,81 . 
stępowy program. W rzeczywistości był wierny tradycyjnej klasyce i „nauce grzeczności”, formule właściwej King’s College, którego studenci byli w większości przypadków dobrze sytuowani, to jest wywodzili się z warstw anglikańskich mieszczan i dżentelmenów. Nie inaczej było z tradycją oratorską, przerwaną przez następcę Johnsona, Mylesa Coopera (1763-1775) i jego Plan of Education. Raczej rosła przewaga klasycznych tekstów, zaś filozofia naturalna i matematyka były w dużej mierze ignorowane ${ }^{33}$.

Kierujący College of New Jersey Aaron Burr (1748-1757) ukonstytuował tam klasyczny kierunek programu nauczania, który był właściwy dla założeń tego okresu i zgodny z podziałami septem artes liberales. Dwóch jego następców zasadniczo utrzymało program w pierwotnej postaci, dodając jednak badania tekstów angielskich. Kolejnemu, Johnowi Witherspoonowi, często przypisuje się względnie szeroki program nauczania i pogląd ten da się utrzymać, zwłaszcza w kontekście college'u w Rhode Island, gdzie na przykład założenia programowe grupowano od początku pod nazwą septem artes liberales. W porównaniu do intelektualnej aktywności poza uczelniami program nauczania New Jersey, podobnie jak sąsiadującego Rutgers, daleki był od oświeconego ${ }^{34}$. Ocena poziomu edukacji liberalnej zależna jest od kontekstu, ten zaś w szczególności dotyczy college'u w Filadelfii.

Od Proposals i Idea of the English School Benjamina Franklina i College of Mirania Williama Smitha wyprowadzić można wiele „liberalnych” czy „postępowych” idei, zaś niektórzy historycy upatrywali w nich źródło nowoczesności w odniesieniu do sztuk wyzwolonych. Jednak angielska szkoła Franklina nie dotyczy „edukacji liberalnej”, zaś Proposals, traktujące o „edukacji liberalnej”, zachwalają studia z jednej strony „,najbardziej ozdobne”, a z drugiej „,najbardziej użyteczne”. Argumentując za studiami $\mathrm{w}$ języku angielskim, Franklin „nie stawał w opozycji do greki i łaciny... dwóch największych spośród istniejących języków, najbardziej ekspresyjnych, płodnych i pięknych". Regularnie cytował Observations on Liberal Education in All Its Branches (1742) autorstwa George'a Turnbulla, który kierował „edukację liberalną” w stronę „szlachetności i arystokratycznego” „dobrego wychowania” celem ukształtowania „liberalnego charakteru” przejawiającego się w „odwadze, stanowczości i męskiej sile”. Podobnie Idea of the English School Franklina, razem z A Sermon on Education Richarda Pe-

${ }^{33}$ D. C. Humprey, dz. cyt., ss. 79-100, 158, 164-176; L. F. Snow, dz. cyt., ss. 56-59.

${ }^{34}$ W. C. Bronson, The History of Brown University, 1764-1914, Providence, R.I.: Brown University 1914, ss. 101-106; E. P. Cheyney, dz. cyt., s. 86; Th. J. Wertenbaker, dz. cyt., s. 93; R. M. Gummere, dz. cyt., s. 64; D. Sloan, The Scottish Enlightenment, ss. 62-64, 112-113. 
tersa, wskazują jasno, że studia nad grecką i łacińską gramatyką i „klasykami” są kluczowym elementem edukacji mającej nazywać się „liberalną" ${ }^{35}$.

Podobnie praca College of Mirania Williama Smith'a sama w sobie może być nazywana znaczącym zwiastunem postępowej edukacji liberalnej. Jednakże w roku 1756, w czasie trwania jego kadencji jako rektora, Smith opublikował nieco bardziej konwencjonalny projekt programu nauczania, który odzwierciedlał ówczesny trzyletni kurs realizowany w Filadelfii. Zachowując rozróżnienie wprowadzone przez Franklina w Idea, Smith nie wzmiankował o szkole angielskiej jako niezajmującej się edukacją liberalną. Zamiast tego starał się kształtować młodych, zaangażowanych mężczyzn na podstawie programu wyraźnie scholastyczno-humanistycznego ${ }^{36}$. Przeto na uczelniach kolonialnych, często wzmiankowanych jako posiadających najbardziej naukowe i postępowe oddziaływanie, termin „edukacja liberalna” w dalszym ciągu podążał za klasycznymi językami i tekstami z cechami tradycji oratorskiej jako dominującej.

Rewolucja przyniosła zmiany. W istocie był to ściśle ten bunt, który wzniecił ogień Oświecenia w Ameryce, zwłaszcza w odniesieniu do edukacji, a osłabił Georgiańską teorię edukacji liberalnej w Anglii. Równość, wolność, kształcenie, postęp, eksperymentowanie i nauka były powiązane ze sobą w umysłach przywódców Rewolucji; prześledzić można wiele z tych koncepcyjnych powiązań, pochodzących od Adama Smitha, Locke'a, Rousseau i Helvétiusa, z kluczowymi postaciami w amerykańskim ruchu niepodległościowym: Franklinem, Jeffersonem, Rushem, Adamsem, Painem. Nic

35 B. Franklin, Proposals, ss. 10, 11, 14, 18, 29-32. Idea of the English School Franklina ani nie zaleca klasyki, ani nie wspomina o edukacji „liberalnej” (ss. 1-8). Pominięcie to dodatkowo akcentuje fakt, że została ona dołączona do A Sermon on Education, Wherein Some Account Is Given of the Academy Established in the City of Philadelphia, Philadelphia: Franklin and Hall 1751, Wielebnego Richarda Petersa, przygotowanej na otwarcie Akademii w roku 1751. Akademia koncentrowała się na nauce gramatyki łacińskiej i angielskiej. Ta ostatnia opisana została przez Franklina, podczas gdy Peters wspomina o gramatyce greckiej i łacińskiej, o „klasykach” i matematyce jako o „wyzwolonych sztukach i naukach” i studiowanie ich ujmuje jako „edukację liberalną”. Peters broni również nauki gramatyki angielskiej, ale czyni to „na użytek tych, którzy mogą nie być predysponowani do studiowania łaciny” (ss. 22-23, 26, 30). Późniejsze podwyższenie statusu łaciny ponad język angielski w szkole było wyraźnie zaznaczone i przewidziane w statucie Akademii.

${ }^{36}$ L. Cremin, American Education: The Colonial Experience, 1607-1783, New York: Harper \& Row 1970, ss. 378-383. Na temat obrońców tezy, że College of Philadelphia był nowoczesny i postępowy zob. L. F. Snow, dz. cyt., rozdz. 3; R. F. Butts, dz. cyt., passim; Th. Hornberger, dz. cyt., ss. 28-29. Pozostali polegali na ich autorytecie: E. P. Cheyney, dz. cyt., ss. 85-87; T. W. Smith, dz. cyt., s. 199. 
dziwnego, że oświeceniowy etos skłaniał także do podejrzeń wobec autorytetu i tradycji i do ataków na dżentelmeńskie cnoty i klasyczną edukację, która je przekazywała ${ }^{37}$. Z tego względu Rewolucję uważać można za katalizator ideału liberalno-wolnościowego tworzącego się w Ameryce.

To nie tak, że teorie edukacji przedłożone przez buntowników zaniedbały tradycję oratorską. W republikańskich pismach na temat wolności, równości, indywidualizmu, dążenia do wiedzy i technologicznego postę$\mathrm{pu}$ - rozwijanych w kontekście narodowych systemów edukacji Benjamina Rusha, Noaha Webstera, Roberta Corama i innych - cechy wyróżniające artes liberales wciąż są wyraźne. Istotnie, Thomasa Jeffersona znaczenie pojęcia aristoi wyrosło z tradycji szlachetnego dżentelmena, zaś jego projekt powszechnej edukacji zakładał pojednanie demokracji i ogłady, podobnie jak pożegnalne przemówienie Washingtona zaadresowane do narodu amerykańskiego. Ta dialektyka „zliberalizowanej ogłady” - aby posłużyć się terminem Lawrence'a Cremina - jest w dalszym ciągu wsparta potężnym amerykańskim zainteresowaniem pismami starożytnych Greków, a przede wszystkim Rzymian ${ }^{38}$. „Zliberalizowana ogłada”, jak widać to w pismach

37 D. G. Tewksbury, The Founding of American Colleges and Universities Before the Civil War, with Particular Reference to the Religious Influences Bearing upon the College Movement, New York: Bureau of Publications, Teachers College, Columbia University 1932, ss. 60 i nast., 142; A. Zimmer, Changing Concepts of Higher Education in America Science 1700 (rozprawa doktorska), Catholic University of America 1938, ss. 38-62; G. C. Lee, Crusade Against Ignorance: Thomas Jefferson on Education, New York: Bureau of Publications, Teachers College, Columbia University 1961, rozdz. 1; P. Nash, Innocents Abroad: American Students at British Universities in the Early Nineteenth Century, "HEQ" 1 (1961), ss. 32-44; H. Kuritz, Benjamin Rush: His Theory of Republican Education, "HEQ" 7 (1967), s. 432-451; W. Sjöstrand, Freedom and Equality as Fundamental Educational Principles in Western Democracy: From John Locke to Edmund Burke, Stockholm: Almqvist \& Wiksell 1973; S. Rothblatt, dz. cyt., ss. 117 i nast.; H. S. Commager, The Empire of Reason: How Europe Imagined and America Realized the Enlightenment, New York: Doubleday 1977. Owi przywódcy wczesnej Republiki stanowili elitę, choć ich stosunkowo egalitarne zobowiązania zostały przedstawione przez pryzmat przychylności do masowej edukacji - znacznie większej niż miało to miejsce w przypadku elit brytyjskich. C. F. Kaestle, 'Beetwen the Scylla of Brutal Ignorance and the Charybdis of a Literary Education': Elite Attitudes Toward Mass Schooling in Early Industrial England and America, w: L. Stone (red.), Schooling, ss. 177-191.

${ }^{38}$ L. Cremin, dz. cyt., s. 419; E. H. Cady, The Gentleman in America: A Literary Study in American Culture, Syracuse, N.Y.: Syracuse University Press 1949, rozdz. 5; G. C. Lee, dz. cyt., ss. 81-103; M. V. Belok, The Courtesy Tradition and Early Schoolbooks, "HEQ" 8 (1968), ss. 306-309; E. A. Miles, The Young American Nation and the Classical World, "JHI" 35 (1974), ss. 259-274; E. T. H. Brann, Paradoxes of Education in a Republic, Chicago: University of Chicago Press 1979, ss. 79-102; M. Reinhold, Classica Americana: The 
z okresu Rewolucji i wczesnej republiki, świadczy zatem o rodzącej się konfrontacji pomiędzy dwoma przeciwstawnymi ideałami edukacji liberalnej.

Konfrontację tę odzwierciedla semantyczny rozwój terminu „liberalny”, uwzględniający w szczególności pojęcia początkowo powiązane z nim negatywnie, takie jak „wolny” czy „nieskrępowany”. Początek sporu nad tym, czy wskazany sens przymiotnika „liberalny” zyskałby uznanie, miał miejsce na gruncie religii, ponieważ dla teologów pojęcie to zawsze było szczególnie wrażliwe na semantyczne perturbacje, mogące w dalszej perspektywie doprowadzić do podważenia ortodoksyjnej doktryny. Wiele głosów krytyki skierowano przeto przeciwko „liberalności” „liberalnych chrześcijan”, których odrzucenie innowierstwa (sectarianism) wyrosło z dżentelmeńskiej, chrześcijańskiej dobroczynności, przekształcając się w epistemologiczną krytykę dogmatycznej ortodoksji ${ }^{39}$.

W odniesieniu do edukacji dialektyczna dwuznaczność terminu „liberalny", objawiająca się zarówno w sensie artes liberales, jak i w koncepcji liberalno-wolnościowej, w krótkim czasie doczekała się wyrazu w serii traktatów opublikowanych jako Cato’s Letters, zwłaszcza w numerze 71: Polite Arts and Learning naturally produced in Free States and marred by such as are not free. Napisane w Anglii i niezmiernie popularne w Ameryce traktaty wspomogły upowszechnienie tej dialektyki za Atlantykiem. Pozo-

Greek and Roman Heritage in the United States, Detroit: Wayne State University Press 1984, ss. 23-49, 95-97, 156-157.

39 Amerykańscy „liberalni chrześcijanie”, zaprzeczając zarazem, że są arminianistami czy deistami, zaczęli stosować termin „liberalny” na określenie „otwartości umysłu” i „wolności od sekciarstwa". Zgodnie z ich poglądem, była to po prostu łaskawa i łagodna odpowiedź na rosnący pluralizm chrześcijaństwa, który już od czasów Reformacji poddawał w wątpliwość tezę, że jakieś wyznanie posiada jedynie słuszną doktrynę, podczas gdy pozostałe trwają w błędzie. Przeciwnicy rozpoznali, że niebezpieczeństwo leży już w początkowym stadium relatywizmu, który na dłuższą metę podważa wszelkie roszczenia do prawdy. W rzeczywistości tolerancja wywodząca się od łagodności „liberalnych chrześcijan” przekształciła się z epistemologicznego wyzwania w ortodoksję. Rzecz jasna, te dwa wątki zostały splecione i nie mogły zostać z łatwością odseparowane, jak pokazuje to obrona „liberalnych chrześcijan” Williama Ellery'ego Channinga z roku 1806: „Narzekasz, że nasz standard nie jest wystarczająco dookreślony. Lecz to jest cecha charakterystyczna naszej liberalności. Im większa różnorodność uczuć, z którymi system będzie harmonizować, czy im mniejsza liczba jego podstaw, tym więcej jest on wart dla liberalnych umysłów". (cyt. za: C. C. Wright, The Liberal Christians: Essays on American Unitarian History, Boston: Beacon 1970, s. 30). A. Heimert, Religion and the American Mind from the Great Awakening to the Revolution, Cambridge: Harvard University Press 1966, ss. 5-23; A. Delbanco, William Ellery Channing: An Essay on the Liberal Spirit in America, Cambridge: Harvard University Press 1981, rozdz. 3. 
stałe kanały zostały zapewnione przez angielskich emigrantów, takich jak na przykład Joseph Priestley. Rozpowszechniając „edukację liberalną” pod koniec osiemnastego stulecia, ten unitariański chemik głosił, że ,wielkim ludzkim celem jest podążanie ku prawdzie i praktykowanie cnoty". Utrzymywał w związku z tym, że „liberalna filozoficzna nauka” lub „filozofia naturalna” czy „filozofia eksperymentalna” powinna być częścią „edukacji liberalnej”, podkreślając zarazem, że „liberalny badacz” wymaga „odpowiedniej ilości wolnego czasu przeznaczonego na czytanie" i że ,studiowanie łaciny i greki jest w dalszym ciągu niezmiernie istotne dla osoby trudniącej się dowolną liberalna profesja" ${ }^{40}$.

Ttum. Agata Łopatkiewicz, Karina Kozłowska

40 J. Priestley, Miscellaneous Observations Relating to Education, More Especially as It Respects the Conduct of the Mind, Birmingham, Eng.: M. Swinney 1788, ss. xiv, 19, 23-27, 45; Cato's Letters, Number 71, Saturday, March 31, 1722, Polite Arts and Learning naturally produced in Free States and marred by such as are not free, w: D. L. Jacobson (red.), The English Libertarian Heritage from the Writings of John Trenchard and Thomas Gordon in the „Independent Whig” and „, Cato's Letters”, New York: Bobbs-Merrill 1965, ss. 186-192. 
